\title{
Agricultural Projects and Food Security in the Post-1994 Democratic Government in Rural South Africa
}

\author{
Andani Aubrey Madzivhandila \\ Department of Development Planning and Management, University of Limpopo \\ Private Bag X1106, Sovenga 0727 \\ Malesela Jim Masenya \\ Department of Development Planning and Management, University of Limpopo \\ Private Bag X1106, Sovenga 0727 \\ Email:malesela.masenya@ul.ac.za
}

\section{Doi:10.5901/mjss.2014.v5n16p647}

\section{Abstract}

The purpose of the paper is to investigate the relationship between agricultural projects and food security in rural South Africa on the post-1994 democratic government. Food insecurity has been a major problem affecting poor people in developing countries. This is a result and effect of some ill-planning of strategies that should facilitate food security. In the case of South Africa, the estimation of poverty show that the proportion of people living in poverty has not changed significantly over the years. However, those households living in poverty have continued to be vulnerable in poverty situation. On the post-1994 democratic government, agricultural projects were introduced as a mechanism of alleviating poverty and food insecurity in rural areas. Most households adopt the agricultural projects to acquire adequate food. However, there are many challenges encountered while practicing agricultural projects. Agricultural projects have been widely promoted as a solution to food insecurity, but its relationship on food security has not been measured in rural areas. The paper discusses the types of agricultural projects practiced food in rural South Africa. The paper also discusses the theoretical background of food security in the democratic South Africa. The paper further discusses the status as well as policies and legislations of food security in South Africa. The paper concludes that although agricultural projects have been initiated as a mechanism of acquiring food in rural households, much is still needed to be done in improving such projects to acquire adequate food.

\section{Introduction}

Rural studies have demonstrated that majority of poor people in developing countries are experiencing food insecurity (Yun and Wen, 2012). The failures of rural development strategy on poverty eradication programs have compelled poor people to in gage in various activities in attempt to reduce food insecurity which is a major challenge to most rural households (Gopal, 2011). Agricultural projects are been considered of having the potential to increase food for rural households (Gopal, 2011). Agricultural projects have been said to have positive relationship with food security in rural households. Most rural households involved in agricultural projects earn good living conditions in terms of food availability across the developing countries (Yun and Wen, 2012).

In a democratic South Africa the circumstances of poor people confronting food insecurity is common. Statistics have demonstrated that about $88 \%$ of people are living in rural settlement in South Africa (Gopal, 2011). About $60 \%$ of the people in rural settlement are experiencing food insecurity. Agricultural projects have increasingly been accepted as a route art of food insecurity in most rural South Africa (Charl and Tasciotti, 2012). Large numbers of people are considering such projects as a remedy of food insecurity in their households (Charl and Tasciotti, 2012). A large number of households have engaged themselves in agricultural projects trying to overcome food insecurity. Positive results have been achieved in most households whom are involved in agricultural projects in terms of food production, but it cannot be said that people who practice agricultural projects in rural South Africa generate enough and sufficient foods (Beneto and Darnhofer, 2012).

Therefore the purpose of the paper is to investigate the relationship between agricultural projects and food security in rural South Africa on the post-1994 democratic government. The paper argues that agricultural projects are important in addressing food insecurity in rural areas, but they must be enhanced so that they bring about adequate and enough 
food in rural South Africa. The paper discusses the types of agricultural projects practiced in rural South Africa. The paper also discusses the theoretical background of food security in the democratic South Africa. The paper further discusses the status as well as policies and legislations of food security in South Africa. The paper concludes that although agricultural projects have been initiated as a mechanism of acquiring food in rural households, much is still needed to be done in improving such projects to acquire adequate food.

\section{Theoretical Background of Agricultural Projects and Food Security in the Post-1994 Democratic South Africa}

The relationship between agricultural projects and food security has not been measured since the post 1994 democratic government in South Africa, but theoretically it has been said that, the those projects provides food to rural people in the country (Beneto and Darnhofer, 2011). Copious people who are involved in agricultural projects are the poor in rural areas; those particular rural poor manage to change the situation they face of food insecurity (Hart, 2010).

Although agricultural projects activities have been seen as an instrument to eradicate food insecurity in rural areas, much is still needed to be done to enhance those projects (Zizza and Tasciotti, 2010). People in rural households practicing agricultural projects still experience food insecurity due to lack the government support in agriculture (Zizza and Tasciotti, 2010). Governments in developing countries often support the rural households in achieving food security and generate income through agricultural projects. As people need food to survive in their daily lives, much has to be done to ensure that all the problems that rural households experience is overcome (Hart, 2010). A joint strategy was formulated as a solution in ensuring that all people are satisfied with the availability of food in rural communities and income generation by all the rural households (Beneto and Darnhofer, 2011). Local governments in supporting rural agriculture ensure that local people got the necessary material which will assists them in the success of agricultural projects which they are practicing, and with necessary training provided on how to overcome poverty using agricultural projects (Beneto and Darnhofer, 2011).

One major theme of the literature on agricultural projects is the discussion of how it can contribute to the food security of households in rural areas as a whole, and households that are engaged in farming within rural boundaries (Zizza and Tasciotti, 2010). One distinction that is often made refers to the extent to which rural households that engage in agricultural projects have some degree of market orientation or are purely producing agricultural goods for ownconsumption (Resder, 2007). There seems to be a consensus that the direct food security purpose prevails, but that a substantial number of rural farmers also sell their produce on the market. Numerous ways through which agricultural projects can, in principle, have an effect on rural food security (Hart, 2010). At the household level, agricultural projects can be a source of income, provide direct access to a larger number of nutritionally rich foods such as vegetables, fruit, and a more varied diet, increase the stability of household food consumption against seasonality or other temporary shortages, and increase the time mothers spend caring for their children, as opposed to non-agricultural activities that is more likely to be located further away from home (Resder, 2007).

The research about the relationship between agricultural projects and food security shows that the projects generate some adequate food for rural people in South Africa (Beneto and Darnhofer, 2011). Households that engage in agricultural projects have access to comparatively cheaper food and to a wider variety of particularly nutritious foods, such as vegetables and products (Beneto and Darnhofer, 2011). The latter mechanism may be particularly relevant should rural food markets, particularly in the poorer neighbor hoods, be inefficient. Under such conditions direct access to food allow households to consume greater amounts of food and a more diversified diet, richer in valuable micronutrients (Zizza and Tasciotti, 2010).

Moving beyond the household to a more aggregate level, agricultural projects account for an important share of the production of some foods, particularly the more perishable ones such as nutritious fruits and vegies (Zizza and Tasciotti, 2010). Through agricultural projects rural households are able to generate more income which satisfies their families in terms of food and also other basic necessities that are needed for a household to survive in South Africa. Most foods are generated through agricultural projects livelihoods in most South African rural areas (Beneto and Darnhofer, 2011).

\section{Types of Agricultural Projects Practiced in Rural South Africa}

There are different types of agricultural projects are being practiced in rural South Africa in trying to overcome the problem of food insecurity. Such types of agricultural projects assist in ensuring that poor people in rural areas have access to sufficient food in rural areas. The most popular agricultural projects practiced in rural South Africa are poultry as well as gardening projects. 


\subsection{Poultry Farm Projects}

Poultry projects have shown a positive impact on food availability for rural households. Amongst all factors, most intensive impact on food availability is by the production of poultry. It is explained that poultry projects such as egg lays and chicken projects increases the availability of food for rural communities. The rural households who practice poultry projects generate food to feed their families in South Africa (Ashley, 1999). The poultry agricultural projects do not only produce only food for rural households, but also a range of other products which could be sold or consumed to successful farmers.

In the case of Tshifulanani Village, Limpopo Province, poultry project was established in 2001. The project produce products such as chicken and eggs which households within the village manage acquire in order to eat. The projects has been said to have brought change in the village in terms of food availability. The project has also manage to bring employment opportunities in the village which makes people to access also income to purchase other unavailable food in the area from markets in order to feed themselves.

\subsection{Gardening Projects}

Gardening is another type of agricultural project practiced in rural South Africa. It is consist of rice, crops, fruits sugar cane, vegetables, potatoes, maize and others (Monde and Anderson, 2006). However, there is evidence that the agricultural sector is shrinking. The proportion of households producing each crop type increased. It should be noted that the proportion of households producing all crops was larger than the proportion of households producing cash crops which are crops for sale since there were households growing crops for consumption (Monde and Anderson, 2006). The proportion of households producing crops in rural areas decreased slightly leading to households without commercial crops to have a higher consumption expenditure and lower poverty than those with subsistence crops. Among the cash agricultural projects households, households with industrial crops experienced the highest expenditure growth rate (Ashley, 1999).

Gardening projects also enables households in rural areas to have access to other food products that could not be potentially produced in the area (Ashley, 1999). These products include sugar, rice and flour and are also the main ingredients of rural diet. And these products are obtained mainly from purchasing them from supermarkets in urban areas (Ashley, 1999). Often rural areas do not have cash to purchase food from supermarkets and that's where gardening projects becomes important for them to acquire food. Gardening projects in the rural South Africa can be regarded as one of the coping strategies of for people to deal with food shortages (Monde and Anderson, 2006).

In the case of Guguka village in the Eastern Cape, South Africa, gardening project was introduced in 2004 and was adopted by local people. The project started off with only two households that were used as demonstration. By the end of 2004; 58 households were involved in the project and said to be successful in terms of generating food in the area. And recently approximately $80 \%$ of households in the village have been said to have joined the project and food availability in the village has improve in both households and the entire village (Madrigal and Edmeades, 2013).

\section{The Status of Food Security in a Rural Democratic South Africa}

South Africa is largely deemed a food secure nation producing enough staple foods having the capacity to import food, if needed in order to meet the basic nutritional requirements of its population (FAO, 2008). Hart (2010) further supported the argument that South Africa seems to be food secure at national level but the same cannot be said about households in rural areas. Reducing food insecurity continues to be a major challenge in South Africa especially in rural areas (Madrigal and Edmeades, 2013). Most people in rural areas are under malnourished and recent food prices have contributed to a greater public awareness of hunger related problems. Most rural households are unsatisfied with food availability and expect to change this situation.

The status of households' food across regions varies substantially. In a cluster analyses on food security conditions in rural South Africa, there are some areas that are classified as absolute food insecurity (Fadima and Omoteso, 2012). The distinctive features of these rural areas are food supply capability, poor food availability, low food safety and also low food consumption. Farm production and purchase food from markets are two major channels for rural areas to achieve food security in South Africa especially in rural areas. According to Fadima and Omoteso (2012), 35\% of the total population, or 14.3 million South Africans are vulnerable to food insecurity. Among these, women, children and the elderly are particularly more vulnerable. In 1996 nearly a third or 2.8 million of households spent less than R1 000 per month, while only $18 \%$ or 1.63 million households spent more than R3 500 per month (Stats SA, 2000). These figures 
disguise the bi-polar mode of income distribution that characterizes that South Africa has many poor, food-insecure people and a few wealthy ones.

The distribution of poverty in the country is uneven in its spread and intensity. Gauteng and the Western Cape are wealthier provinces with the least number of poor households at less than $12 \%$ each. On the other extreme end, the Free State, Eastern Cape and Northern Provinces have the worst of poverty in South Africa. In the middle group are Mpumalanga, KwaZulu-Natal, Northern Cape and North West Provinces (Gibbs and Cocklin, 2013). The average household of Gauteng spends about R7 742 per month compared to R2 665 in the Eastern Cape. Within the provinces there is an also unequal level of poverty according to urban and rural location, race and gender (Gibbs and Cocklin, 2013).

In Limpopo Province agricultural projects are seen as a strongest mechanism to generate food. Most households are involved in agricultural production to sustain level of food security around the Province (Hart, 2010). Households which are involved in the projects were seen success in terms of food insecurity problem and also low income. Measured by its total current income, Limpopo is ranked sixth of all the provinces in South Africa in terms of total income (Madrigal and Edmeades, 2013). In per capita income terms, however, the province is the poorest. As is the case with most of the other provinces in South Africa, Limpopo is marred by high poverty rates, inequalities in the distribution of income between various population subgroups, and unemployment (Punch, 2007). Poverty and unemployment in South Africa are often rural phenomena, and given that many of the rural inhabitants are linked to agricultural activities.

\section{Policies and Legislations on Food Security in South Africa}

The current food security challenge in South Africa consists of two dimensions: the first tries to maintain and increase South Africa's ability to meet its national food requirements, and the second seeks to eliminate inequalities and poverty amongst households that is made apparent by inadequate and unstable food production, lack of purchasing power, poor nutritional status and weak institutional support networks and disaster management systems May 2004. Food security is seen as a Constitutional Right in South Africa and guarantees its citizens the right to have access to sufficient food and water, and that "the state must by legislation and other measures, within its available resources, avail to progressive realization of the right to sufficient food (Winrock, 2008). Despite national food security, many South African households experience continued food insecurity and malnutrition and unemployment.

The maintenance of timely, accurate and relevant agricultural economic and statistical information enables the production of a monthly Food Security Bulletin which provides an early warning system that enables Government to implement proactive and timely interventions in response to impending food shortages (Herrero, 2013). The Government of South Africa's Agricultural Economic Research and Analysis Programme provides timely, accurate and relevant agricultural economic and statistical information on a quarterly basis to inform decision making on production by all participants in agricultural sector. Information provided includes, monthly crop forecasts and the quarterly livestock estimates; the quarterly Monitoring Report on the economic performance of the sector; the quarterly Agricultural Economic Review and Forecast Report, the monthly Food Security Bulletin, the quarterly Crops and Markets Report; weekly Price Watch; the annual Africa Economic Review and Outlook, and the Economic Review of South African Agriculture (Backerberg, 2009). In order to improve the accuracy of crop estimates, a new producer independent crop estimate system was developed and implemented in four provinces and the preliminary results are promising (Backerberg, 2009).

The development of agriculture in South Africa is often viewed solely as the technical advance of large-scale commercial farming (Winrock, 2008). The proponents of this view believe that agriculture can only contribute to the economy through commercial production, and that smaller and medium-scale agriculture, based upon diversified production, family labour and lower technologies, has little to offer in terms of aggregate production and incomes from farming (Backerberg, 2009). These are some of the policies passed before 1994 that contributed to the creation of this system that have resulted in poverty, inequalities and increased household food insecurity.

These are some of the policy reforms passed post 1994 by the democratic elected government aimed at redressing the created imbalances of the past. The Constitution of the Republic of South Africa 1996; which is aimed at creating an overall framework of policies that are based on the principles of justice and equality (Lund, 2008). The Marketing of Agricultural Products Act 1996, which replaced the previous marketing regulations and substantially reduced state interference in agriculture marketing and product prices. The White Paper on Land 1997, which links land reform to the promotion of equity of land ownership, and the Land and Redistribution Programme 2000, designed to provide financial support to the previously disadvantaged to access agricultural land (Winrock, 2008). The Comprehensive Agricultural Support Programme was established in 2004 to provide post-settlement support for agricultural development 
to beneficiaries of Land and Agrarian Reform Programs (Winrock, 2008).

\section{Conclusion}

It is important for agricultural development initiative to take note of reasons why rural households in South Africa engage in agricultural projects. The relationship between agricultural projects in rural areas must be measured to check whether those projects are doing enough for rural households to acquire adequate food in their respective families, and also allocate the land to people or households which are practicing the agricultural projects in rural areas as it is the most important tool of practicing agricultural projects.

The South African government needs to develop or accelerate its existing interventions to effectively target and improve the lives of the poor and in particular those going without food in rural areas. The government's approach also needs to be innovative with regard to new, more comprehensive and purpose specific approaches to the assessment of food insecurity in the country. More specifically, a national representative survey that includes questions that focus exclusively on food security, but also encompass a variety of other related fields such as employment, income and health, would appear to be essential.

Furthermore, it is also urgent that an affordable and regular national system be set up to monitor food security status. There is a need for more reliable nationally representative data to monitor and evaluate household food security status in rural areas. There is also a need for more localized studies to interpret the causes and implications of household food insecurity in different contexts and at different levels. Such studies will contribute to a better understanding of the national data and permit evidence based policy decisions. The most efficient immediate approach would involve the inclusion of a special food security module in the General Household Survey. This would offer a low cost approach to drawing together data on food consumption, consumer choice, aligned to other household information in a large annual population survey. Improved agricultural practices and skills development also needs to be put in place for poor people in rural areas to know more about agriculture and participate in order for them to acquire adequate food in their households.

\section{References}

Agrekon, B. (2009). Households' food security status in rural areas. Food Policy Journal 48: 353-370.

Ashley, F. (1999). Community gardening in rural regions. Rural Community Gardening 18: 1-9.

Backerberg, G. (2009). Household food security status in South Africa. Rural Agriculture Journal 1(7): 227-300.

*Beneto, C. and Darnhofer, I. (2011). Assessing the impact of improved agriculture on rural households' income poverty. Food Policy Journal 36: 78-90.

Charl, S. and Tasciotti, B. (2012). Sustainable agriculture and food Security in LDCs. Journal of Rural Studies 2: 13-24.

Cornwell, L. (2004). Income poverty in rural areas. Journal of Development Administration 34: 51-63.

Datar, C. (2008). Income poverty situations in Africa. Journal of Rural Development 17: 737-749.

Donaghy, T.B. (2006). Food security status in rural areas. International food Science Review 25: 393-410.

Drechsler, D. and Lindberg, C. (2010). Determinants of food security in rural areas. Poverty in Focus 13: 10-21.

Duarte, J. (2009). Food purchasing power in rural households. Food Policy Journal 33: 22-45.

Fadima, K.S. and Omoteso, O.A. (2012). Food security and poverty of rural households. Agriculture Research Center Journal 1: 56-69.

FAO. (2008). The State of the Food Insecurity in the World 2005. FAO. Rome

Gibbs, D. and Cocklin, C. (2013). Farming GM as a food security solution. Journal of Rural studies 29: 59-70

Hart A. (2010). Food security in rural areas. Agriculture Policy Journal 3: 26-51

Herrero, M. (2013). Determinants of food security in South Africa. Agricultural Policy Journal 13(5): 10-33.

Lund, M.S.P. (2008). Reducing Food Poverty with sustainable agriculture. Food Policy Journal 40(17): 30-56.

Madrigal, L. and Edmeades, S. (2013). Food security and public agriculture in rural areas. Food Policy Journal 40: 1-13.

May, D.S. (2004). Policies about food security in South Africa. Journal of Rural Studies 2: 17-39.

Monde, N. and Anderson K. (2006). Making home gardening a visible livelihood option in rural South Africa. Journal of Rural Studies 3: 1-12.

Punch, K.F. (2007). Development effective proposal. International Journal of Proposals 34: 23-40.

Raphel, O. and Matin, Q (2010). Impact of off- farm income on food security and nutrition. Food Policy Journal 35: 303-311.

Resder, P. (2007). Global poverty assessment. International Journal of Proposals 45: 10-36.

Stats SA. (2000). Measuring food insecurity in South Africa. Pretoria: StatsSA.

Yun, L. and Wen, Y (2010). Households food security in poverty-stricken regions. Agriculture and Agricultural Science Procedia Journal 1: 386-395.

Zizza, A. and Tasciotti, L (2010). Rural agriculture, poverty, and food security. Food Policy Journal 35: 265-273. 